\title{
IMPROVEMENT OF THE MECHANISM OF STATE REGULATION OF INVESTMENT IN THE INNOVATIVE DEVELOPMENT OF THE AGRARIAN SECTOR
}

\author{
Vyacheslav Klochan', Iryna Klochan ${ }^{2}$ \\ Mykolaiv National Agrarian University, Ukraine
}

\begin{abstract}
The purpose of this article is to analyse the main factors of innovative development of the agrarian sector, to run a research on investment support of innovations, which will enable to determine the main directions of improvement of the mechanism of state regulation of investment in the innovative development of the agrarian sector of the country. The methodology of the research is to substantiate the necessity of state support of innovative development of the agrarian sector, as a priority direction of its investment support, which involves the implementation of a set of measures to change existing trends, reducing the amount of financing of scientific and technical works, and reducing the number of research institutions involved in the development and implementation of innovative products in agriculture, while creating an institutional environment for development and implementation of agrarian innovations through the national and regional investment funds, promotion of the implementation of scientific developments into production by expanding the availability of financial resources through public and private partnerships and the commercialization of research results. The results of the study indicate that Ukraine's agriculture has potential opportunities to improve its competitive advantage in world markets. However, in order to strengthen them, it is necessary to take a number of measures: to form economic and political support for agricultural enterprises using scientific equipment and new technologies; to ensure the creation and distribution of a network of innovative funds to support innovative business at different levels; to orient all loans and support in Ukraine to implement innovative projects in specific areas of production development, including innovation and investment support of agricultural enterprises; Provide additional tax incentives for enterprises producing innovative products, which will increase the financial resources for the implementation of innovation projects and innovation program; clearly identify the legislative provision of funding and form a mechanism to support small businesses. Practical meaning. The identified development priorities can serve as a basis for creating conditions for the domestic agricultural enterprises to implement the offensive strategy in foreign markets, supporting constructive competition in the domestic market, which will stimulate agrarian formation to innovation, ensure close integration of production and science, in order to facilitate the advance development of scientific and technological sphere. Value/Originality. The results of the study indicate that improving the investment provision of the agrarian sector of the economy involves determining the prospects for its long-term development based on scientifically based methodological approaches, the use of which allows measuring changes and expected socioeconomic outcomes.
\end{abstract}

Key words: investment, investment support, innovation, agriculture, state regulation, financing.

JEL Classification: E22, E65, G28, O13, O31, Q16

\section{Introduction}

The innovative development of Ukrainian agriculture is based on the implementation of the state agricultural investment policy aimed at activating innovations as a major component of the overall strategy of increasing national competitiveness. The identified priorities are the creation of conditions for the domestic agricultural enterprises to implement the offensive strategy in foreign markets that will support for constructive competition in the domestic market, which will stimulate agrarian formations to innovations, ensure close integration of production and science, in order to promote the advanced development of the scientific and technological sphere.

Corresponding author:

${ }^{1}$ Department of Management and Marketing, Mykolaiv National Agrarian University.

E-mail: vvclochan@gmail.com

${ }^{2}$ Department of Economic Cybernetics and Mathematical Modelling, Mykolaiv National Agrarian University.

E-mail: ivclochan@gmail.com 


\section{Financing of the innovative activity in the Ukrainian agriculture}

In modern conditions of the reduction of investment activity, a significant depreciation of fixed assets leads not only to deceleration of the extended but also further reduction of the simple reproduction. The overcoming of certain problems requires the formation of a rational structure of production potential and creation of conditions for its more effective use. This testifies the need for the transition to an innovative type of development and improvement of the mechanism of state regulation of investing innovations in the agrarian sector of the economy.

It should be noted that most scientists interpret innovation activity in agriculture as an integrated process of the creation of new or more productive high-yield varieties, livestock, elite seeds, high-yield agricultural machines and aggregates, the introduction of advanced technological, organizational, economic, and managerial decisions, etc. (Yatsenko, 2004). In this regard, Table 1 represents the main indicators of financing innovative activity in Ukrainian agriculture.

Over the past six years, the number of scientific organizations involved in the development and implementation of innovative agricultural products has decreased by $27 \%$, while funding for scientific and technical work is fluctuating, but it is steadily decreasing because of the state budget. Financing scientific works using own funds of scientific institutions has doubled. All this indirectly indicates the decline of scientific institutes, the reduction of research and innovation products in the agrarian sector.

\section{The main factors of innovative development of the agrarian sector}

The innovative development of agricultural producers involves the comprehensive use of hightech factors of production in the technological, organizational, economic, and managerial spheres to ensure the stable and high competitiveness of agricultural products in the domestic and foreign markets. In the formation of the main directions of innovative development of agricultural commodity producers, the priority should be on the complexity, which means participation in the innovation process of all subjects of the innovation cycle (developers of ideas, entrepreneurs, investors, etc.). So far, the imperfection of the mechanisms of the innovations introduction, the lack of a holistic system of scientific and technical information do not allow to implement an effective scheme of interaction between research institutions and practices.

A preliminary analysis of the conditions and factors influencing the innovative development of the agrarian sector has allowed dividing them into negative (restraining innovative development) and positive (which contribute to accelerating innovation processes). Negative ones include:

- the risk of innovative processes in the agrarian sector; - underfunding of innovative activity in the agrarian sector;

- absence of a holistic state innovation policy and direction of the strategy of agricultural development;

- insufficient staffing of agro-industrial production in the field of innovation management.

Positive factors:

- departure from the administrative management of the economy;

- variety of the management forms;

- desire to increase professional staffing capacity;

- growing demand for innovations in a certain stratum of agricultural commodity producers.

At the present stage of development of the national economy, connected with the entry and adaptation to the requirements of the world market, we observe the emergence of a complex situation of domestic business, especially in the agricultural sector of the economy. This situation is determined, first of all, by the low competitiveness of agrarian enterprises in comparison with foreign producers. Such a situation requires the active introduction of domestic and world experience in agrarian business activities that are in line with contemporary world development trends (Ilchuk, Sadchykov, 2015).

Table 1

The key indicators of financial expenses on performing of scientific work on funding sources and industries (agricultural sciences)

\begin{tabular}{|l|c|c|c|c|c|c|c|}
\hline \multicolumn{1}{|c|}{ Indicators } & 2011 & 2012 & 2013 & 2014 & 2015 & 2016 & 2016 in \% till 2011 \\
\hline The number of scientific institutions & 161 & 151 & 135 & 127 & 132 & 118 & 73,29 \\
\hline $\begin{array}{l}\text { Financing of expenses for scientific works, } \\
\text { total, million UAH }\end{array}$ & 564,0 & 647,0 & 636,1 & 590,8 & 605,4 & 557,9 & 98,92 \\
\hline $\begin{array}{l}\text { including at the expense of the state budget } \\
\text { funds }\end{array}$ & 443,7 & 512,7 & 489,4 & 451,1 & 411,9 & 396,5 & 89,36 \\
\hline $\begin{array}{l}\text { The volume of scientific works, performed } \\
\text { for own funds of scientific institutions, } \\
\text { million UAH }\end{array}$ & 88,6 & 95,8 & 103,3 & 81,0 & 124,5 & 219,2 & 247,40 \\
\hline
\end{tabular}

Calculated by the author on the basis of data from the State Statistics Service of Ukraine, 2017 


\section{The investment provision of innovations in agriculture}

Innovative development of the agrarian sector of the economy depends on the investment of the main branches of agriculture. Creating conditions for macroeconomic balance will increase the business activity of agricultural producers as a result of the targeted influence of aggregate factors (investment, marketing, production, etc.) to ensure the development of their economic, investment, and innovation potential.
The dynamics of investment attraction is not the only thing that has been analysed during the study of investment support. Also, the ratio of economic and investment indicators characterizing the degree of volatility of the investment activity of the agrarian sector (Fig. 1) was analysed.

Thus, investment support for innovation is the actual result of a complex dynamic interaction of its components, potential investment opportunities and the likelihood of achieving a definite final

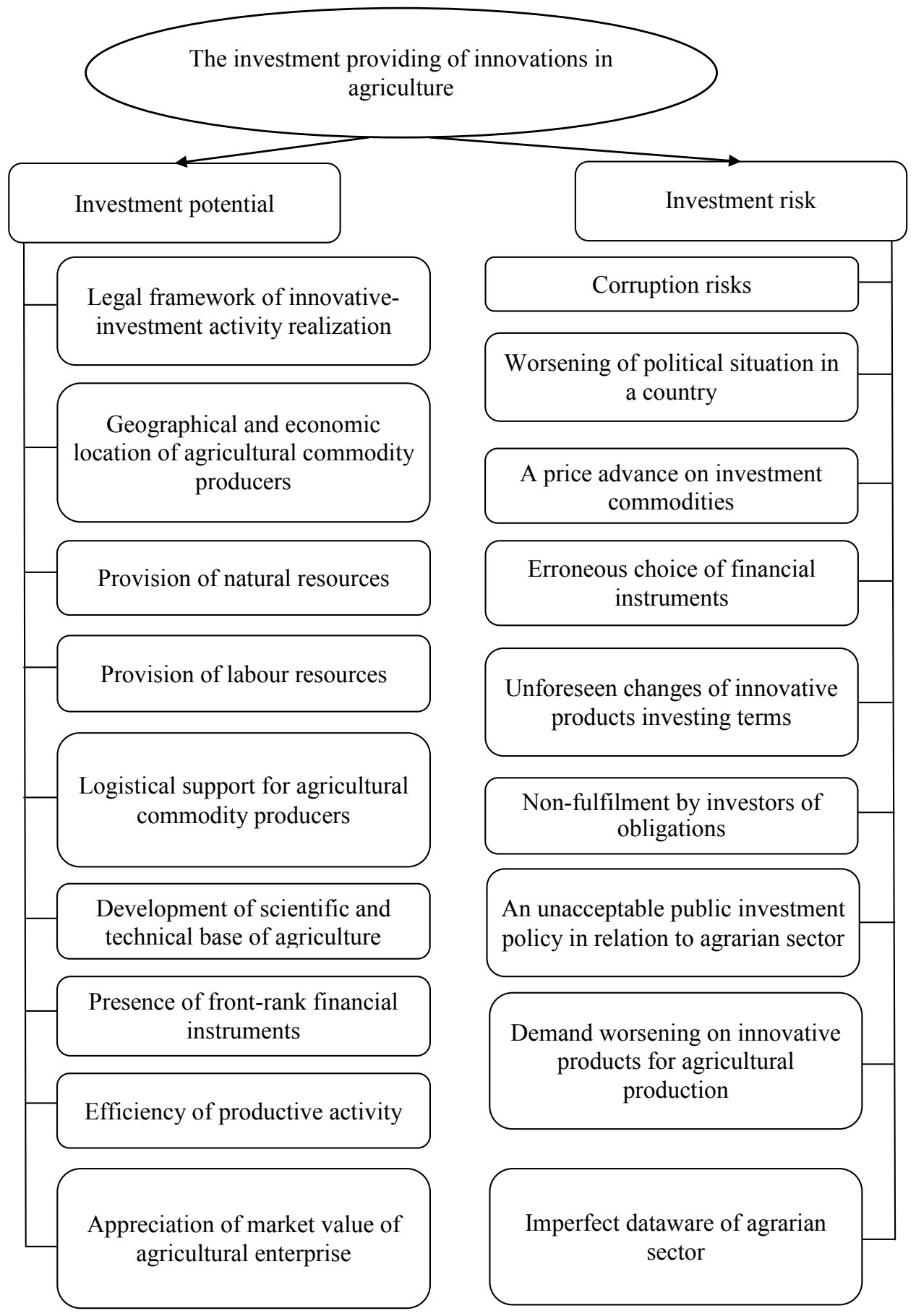

Fig. 1. The investment provision of innovations in agriculture 
goal of the innovative activity of an agricultural producer. In order to create favourable conditions for innovation and investment development of the production activity of agricultural producers in Ukraine, it is necessary to minimize the financial risks of agriculture that hold back potential investors. Measures for the financial improvement of the agrarian sector should become a priority in the state agrarian policy.

\section{State regulation of the innovative development process in agriculture}

Domestic economists distinguish three main strategic directions of resource and technological renewal of the agrarian sector of the economy (Trehobchuk, 1997):

- application of technologies that contribute to cheapening of agricultural products without significant losses of its quality;

- introduction of technologies that potentially give an opportunity to improve the quality of food and agrarian raw materials;

- the use of technologies and biological means that ensure the production of environmentally friendly products and guarantee safe agricultural activities.

Economic analysis shows that in Ukraine, the innovation sphere occupies a small proportion of the total volume of production (about 10\%). Moreover, the main principles of the state innovation policy in the field of agriculture are:

- definition of state priorities of innovative development;

- formation of the regulatory framework of innovation activities;

- creation of conditions for the development of domestic scientific and technical potential;

- ensuring the cooperation and interaction of science, education, production, financial, and credit sphere (Kabinet Ministriv Ukrainy, 2008).

In order to implement the state innovation policy of Ukraine in 2005, the State Agency for Investments and Innovations was created (later reorganized into the State Agency of Ukraine for Investments and Development), which participates in the formation and implementation of state policy in the investment field and innovation activities and prepares proposals for the state support in realization of investment and innovation projects in the real sector of the economy.

According to the statutory documents, in the process of competitive selection of innovation and investment projects for their financial support at the expense of the state budget, the following criteria are taken into account:

1) technological or scientific-technical level of the project;

2) the competitiveness of products and the prospects of markets;
3) cost-effectiveness of the project (an estimation of the planned volume of profit from the project implementation, payback period, etc.);

4) the budget efficiency of the project;

5) availability of resource and energy saving technologies in the project;

6) social significance of the project (creation of new jobs, wage growth, improvement of working conditions);

7) possible impact of the project on the environment.

Implementation of the effective innovation and investment support for the production of agricultural commodity producers in modern conditions is a guarantee of their effective activity. It also provides an opportunity for growth and provides long-term competitive advantages. For this purpose, the scope of innovations is regulated by the Ukrainian laws called "On Science and Scientific and Technical Activity", "On Scientific and Scientific-Technical Expertise", "On Special Regime of Investment and Innovation Activity of Technological Parks", "On Priority Directions of Innovation Activity in Ukraine", "On Investment Activity", "On Protection of Rights to Inventions and Utility Models", "On Protection of Rights to Trademarks for Goods and Services" and other laws in the patentlicensing sphere, laws on the creation of special (free) economic zones and territories of priority development, tax laws, etc. (Ilchuk, Sadchykov, 2015).

The innovation process in the agrarian sector is characterized by two main features:

1) the developing idea is undergoing technical testing and is implemented in agro-industrial production;

2) the social necessity of development and the significance of its results for the agrarian sector and the national economy as a whole.

The initial stages of the innovation process in the agrarian sector, namely, fundamental and applied research, are carried out in Ukraine mainly by a system of research institutions of the National Academy of Agrarian Sciences of Ukraine and higher educational institutions of the agrarian sector. However, due to the lack of proper funding, outdated material and technical base, only a small number of scientific institutions are conducting research on the selection of promising varieties of plants and animal breeds based on genetic engineering methods, biotechnological methods of pest control, and nanotechnologies. Implementation and development of innovations are constrained by other factors, among which the most important are low solvency of farms and the lack of reliable and complete information about domestic scientific developments in the agriculture (Yermakov, Hrebennikova, 2011).

Innovations in the agrarian sector of the economy require information support from the state side and proper financing, which is important when entering the market of scientific and technical products, as well as competition with foreign counterparts. This plays 
the crucial role in the import of agricultural machinery, seeds and plant protection products. The financing of scientific development for agriculture needs to be carried out at all stages of the innovation process, as the introduction of development into production should stimulate the demand for research of the domestic scientific institutions. Functioning of agrarian science in conditions of the uncertainty of the reasonable price for scientific products and legislative regulation of this issue does not contribute to the process of innovation. At the same time, studying the world experience of the stimulation of innovation activity shows that the importance of the innovative component in the development of economies of foreign countries is constantly increasing, and activation of innovation activity is fully supported.

Innovative development of the agrarian economy is ensured by an appropriate innovation policy implemented through innovation and investment development of the agricultural activity of agricultural producers. Modern innovation policy is a set of scientific and technical, production, managerial, financial and sales and other activities related to the promotion of new or improved products on the market; this is a complex and risk-free process, which course is determined by the initial technical, financial, economic, and social conditions (Hudzynskyi, Ivaniuta, 2010).

The state policy in the field of innovation policy is to provide significant structural changes in the economy, technology or technologies. Its implementation includes: material and financial provision of longterm programs for the development of scientific and technical infrastructure (laboratories, research centres); creation of the mechanism of financing innovations with high risk; implementation of scientific and technical programs that require inter-sectoral cooperation or "joint work" of science with agriculture; satisfaction of strategic and social needs.

An innovative potential as a system of factors and resources plays a key role in ensuring the effective development of innovative processes in agricultural production, which includes:

- market potential reflects the level of availability of the company's opportunities for external market needs of innovations, which are constantly generated by the relevant market environment;

- intellectual potential - determines the possibilities of generating innovations, bringing them to the level of new technologies, structures, organizational and managerial decisions in the development of enterprises; - human potential - characterizes the capabilities of employees of the enterprise to apply new knowledge and technologies, organizational and managerial decisions, in order to develop and produce new innovative agrarian products;

- technical and technological potential - the ability to quickly reorient production capacities and establish a cost-effective production of new agricultural products that meet market needs;

- informational potential - information security of agrarian enterprises, the degree of completeness and accuracy of information necessary for effective innovative solutions;

- financial potential - compliance with the financial state of investment attractiveness, creditworthiness and the system of effective financial management of enterprises in the agrarian sector to ensure the sustainability of innovation activities at all stages of the innovation cycle;

- motivational potential - characterizes the company's ability to harmonize and coordinate the various interests of the subjects of the innovation process: developers of innovations, investors, suppliers, etc.;

- communicational potential - the existence of communication links that reflect the level of certainty and effectiveness of the company's interaction with the elements of the environment, which contribute to the goal of innovation activities;

- research potential reflects the availability of created reserves of research results sufficient to generate new knowledge, the ability to conduct research to test ideas, innovations, and the possibility of their use in the production of new products (Ilchuk, Sadchykov, 2015).

Stimulation of the development of the innovative potential of agricultural sectors can be achieved in various ways. However, the main two areas should be identified:

- creation of incentives in order to obtain additional profits from agricultural producers, investments aimed at the development of innovations, markets. As a result of the implementation of new schemes for the promotion of products and the provision of innovative activities;

- the emergence of the workers' personal interest before the innovation renewal of production since, at the expense of obtaining additional profit their income becomes stable over a longer period of time, provided by the innovative renewal of fixed assets (Bezpiata, 2016).

The system of state regulation of the development of innovative agrarian sector should be expressed in the development of the legislative and regulatory framework aimed at activating the innovative activity of agricultural producers, development and implementation of innovation and investment policy, support for the information-analytical environment of innovative processes (Fig. 2).

Thus, improvement of government control mechanism and support for agricultural commodity producers' innovative development process is a step towards the creation and improvement of legislation that regulates the innovative activity of agricultural commodity producers. 
Government control over innovative development process in the agrarian sector of the economy

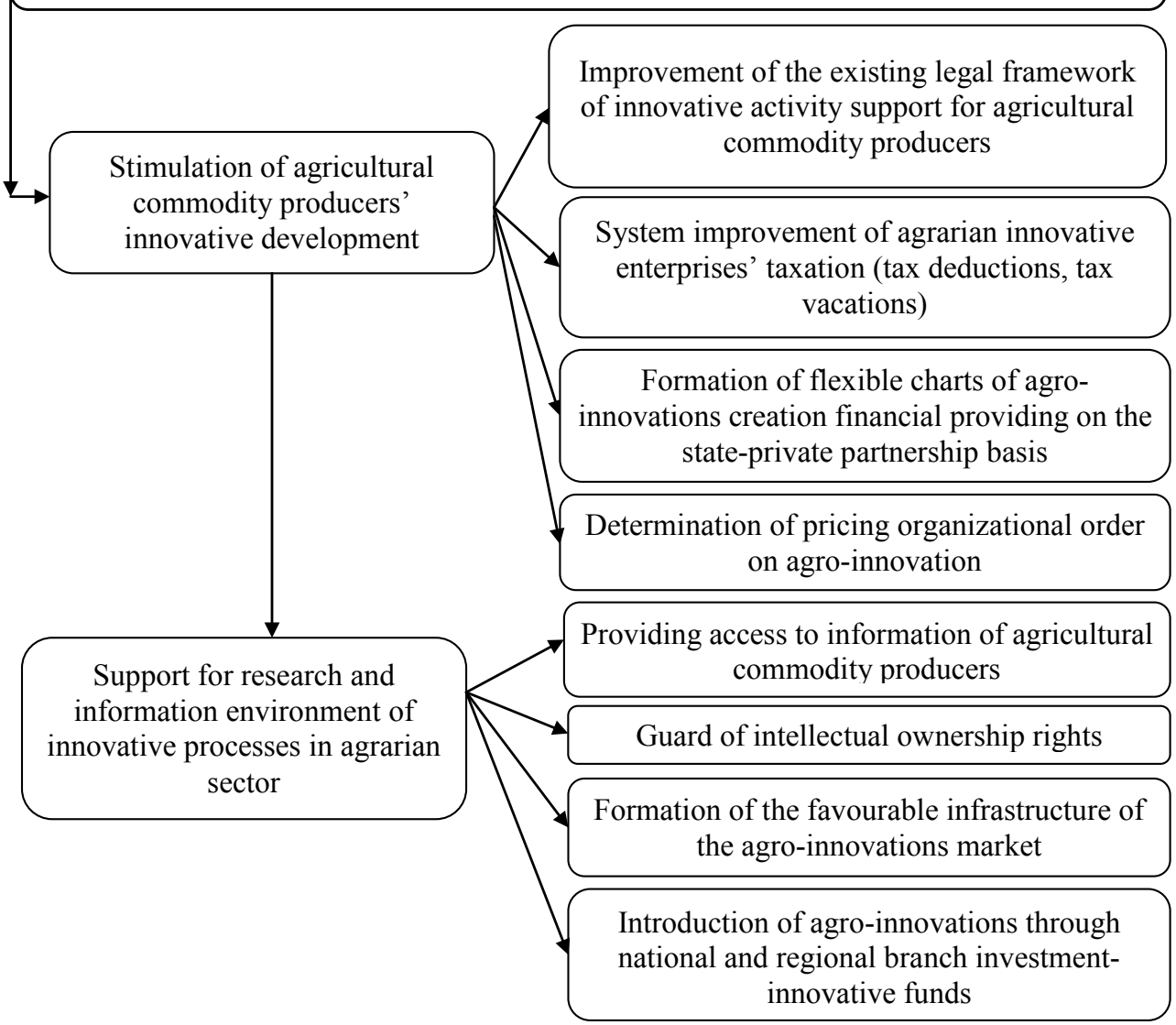

Fig. 2. Improvement of government control system of the innovative development process in agriculture

\section{Conclusions}

Further, permanent, development of Ukraine agriculture is possible only on the basis of the effective innovative-investment providing of agricultural commodity producers' productive activity. Agriculture of Ukraine has potential possibilities for the improvement of the competition positions on world markets, however, for their strengthening, it must carry out the row of events: to form economic and political support for agricultural enterprises that use a since equipment and New Technologies; to provide creation and distribution of innovative funds network for the support for innovative business on different levels; to orientate all credits and having a special purpose help in Ukraine on the realization of innovative projects after certain directions of production development, including the innovative-investment providing of agricultural enterprises; give additional tax deductions for the enterprises-producers of innovative products that will allow increasing financial resources for the realization of innovative projects and innovative program of enterprise; clearly define directions of the legislative providing in relation to financing and form the mechanism of small business support.

\section{References:}

Ambrosov V.Ia., Onehina V.M. (2009) Zabezpechennia derzhavnoi pidtrymky silskohospodarskoho vyrobnytstva $\mathrm{v}$ umovakh chlenstva Ukrainy u SOT [Providing of agricultural production state support in the conditions of membership of Ukraine in WTO]. Economy of agribusines, no. 2, pp. 15-24.

Bezpiata I.V. (2016) Investytsiine zabezpechennia ahrarnoho sektora ekonomiky: monohrafiia [Investment provision of the agrarian sector of the economy: monograph]. Mykolayiv: MNAU. (in Ukrainian)

Bezpiata I.V., Klochan V.V. (2016) Struktura kapitalnykh investytsii v silskomu hospodarstvi Ukrainy ta osnovni dzherela yikh formuvannia [The structure of capital investments in agriculture in Ukraine and the main sources of their formation]. Bulletin of Dnipropetrovsk State Agrarian and Economic University. Economic sciences. no. 2(40), pp. 124-129. 
Hudzynskyi O.D., Ivaniuta P.V. (2010) Derzhavna polityka innovatsiinoho rozvytku natsionalnoi ekonomiky [Public policy of national economy innovative development]. Investments: practice and experience. no. 18, pp. 98-100.

Ilchuk V.P., Sadchykov V.S. (2015) Kontseptsiia orhanizatsiino-ekonomichnoho zabezpechennia innovatsiinoho rozvytku pidpryiemstv haluzi roslynnytstva [Conception of organizationally-economic providing of plant-grower industry enterprises innovative development]. Chernigiv: CHNTU. (in Ukrainian)

Kabinet Ministriv Ukrainy (2008) Prohrama diialnosti «Ukrainskyi proryv: dlia liudei, a ne politykiv» [The program activity for "Ukrainian breach: for people, but not politicians"], Kyiv. (in Ukrainian)

Trehobchuk V. (1997) Stratehiia i taktyka resursno-tekhnolohichnoho onovlennia natsionalnoho APK [Strategy and tactics of the resource-technological updating of national AIC]. Strukturni zminy ta investytsiini problemy ukrainskoi ekonomiky [Structural changes and investment problems of the Ukrainian economy]. Kyiv, pp. 36-38.

Yatsenko V.M. (2004) Formuvannia ta realizatsiia investytsiino-innovatsiinoho rozvytku silskoho hospodarstva [Forming and realization of agriculture investment-innovative development]. Economy of agribusines, no. 12, pp. 68-74.

Yermakov O.Iu., Hrebennikova A.A. (2011) Innovatsiino-investytsiine zabezpechennia vyrobnychoi diialnosti silskohospodarskykh pidpryiemstv: monohrafiia [The Innovative-investment providing of productive activity of agricultural enterprises: monograph]. Kyiv: Agrar Media Group. (in Ukrainian) 